\title{
Assessment for Yield and Nutritional Profiling of Groundnut with the Help of Allele Specific Markers for Desirable Fatty Acids
}

\author{
Tinee Adlak, Sushma Tiwari*, Neha Gupta, M. K. Tripathi, \\ R. S. Sikarwar, Ritu Sastya and Versha Gupta
}

Rajmata Vijayraje Scindia Krishi Vishwavidyalay, College of Agriculture, Gwalior, India

*Corresponding author

Keywords

Groundnut, Genetic

Diversity,

Morphological

Traits, nutritional

traits, UPGMA tree

Article Info

\section{Accepted:}

15 January 2021

Available Online:

10 February 2021
Groundnut (Arachis hypogaea L.), is one of the most important oil seed as well as protein rich crop, grown all over the world. The present investigation was carried out for genetic analysis of yield and high oleic acid using allele specific molecular marker in 48 groundnut genotypes. Highly significant and positive correlation was found between number of pods per plant $(\mathrm{r}=0.399)$, number of seeds per plant $(\mathrm{r}=0.575)$ and harvest index $(\mathrm{r}=0.400)$ at $1 \%$ significance level. Assessment of high oleic acid content using gene-based markers was done using allele specific markers for FAD2A and FAD2B allele. The UPGMA clustering revealed that 12 genotypes forming group with check variety Sunoleic 95R while 35 genotype formed separate groups. In selected lines total protein, oil and fatty acid was estimated using NIR spectroscopy. Total oil was ranging between 46 to $51 \%$, linoleic acid 21 to $49 \%$, oleic acid 28 to $61 \%$, palmitic acid 9 to $14 \%$, stearic acid 1 to $3 \%$, protein 18 to $31 \%$ and moisture level was between 2 to $11 \%$ for groundnut seed samples. The highest $\mathrm{O} / \mathrm{L}$ ratio was in Sunoleic $95 \mathrm{R}$ and lowest in GPBD4. Screening of these advance lines and germplasms identified superior breeding material to be used for varietal improvement of groundnut.

\section{Introduction}

Groundnut (Arachis hypogaea L.) known as earthnut or peanut or monkey-nut, an allotetraploid (AABB) derived from diploid species Arachis duranensis (AA) and Arachis ipaensis (BB) having $2 \mathrm{n}=40$ pairs of chromosomes. In India, about $81 \%$ of the total groundnut produced is used for oil extraction,
$12 \%$ for seed, $6 \%$ for direct consumption and $1 \%$ for export trade. Groundnut oil consists of triglycerides (96.1-96.4\%), phospholipids (2.4- $2.9 \%)$, sterols $(0.69-0.80 \%)$, free fatty acids (0.1-0.4\%) and glycolipids (0.10$0.14 \%$ ). Eight fatty acids can be routinely detected in peanut seeds; however, two major fatty acids, oleic acid (C18:1, D9) and linoleic acid (C18:2, D9, D12), account for 
approximately $80 \%$ of the fatty acid composition (Moore et al., 1989, Norden et al., 1987). Major fatty acids in groundnut oil are palmitic acid (8-11\%), oleic acid (36$52 \%)$ and linoleic acid (24-43\%). The biochemical difference between these two fatty acids is that linoleic acid contains one more double bond at the $\Delta 12$ position of the hydrocarbon chain than oleic acid. Fatty acid desaturase (FAD) enzyme facilitates the conversion of oleic acid to linoleic acid by adding double bond to oleic acid (Töpfer et al., 1995). This enzyme is coded by two homologous genes (ahFAD2A and ahFAD2B) located on A and B sub-genomes of groundnut. Consuming oils with high levels of oleic acid is beneficial to human health because it reduces low-density lipoproteins, maintain high-density lipoprotein, slow down atherosclerosis, and reversing the inhibitory effect of insulin production. As a result, groundnut oil with a high percentage of oleic acid is preferred, and the oil quality can be determined by the oleic acid and linoleic acid $(\mathrm{O} / \mathrm{L})$ ratio. First groundnut, mutant line, F435 with $80 \%$ oleic acid and $2 \%$ linoleic acid was reported in 1987 by Norden et al., by applying conventional breeding methods, the first ever high oleate groundnut line, SunOleic 95R (80\% oleic acid) was bred in USA (Gorbet $e t$ al., 1997).

The chemical composition of peanut oil is highly influenced by environmental factors like season, temperature, humidity, geographic location, and growing conditions (Grosso et al., 1994). In general, lower temperature $\left(22-29^{\circ} \mathrm{C}\right)$ is associated with more linoleic acid synthesis due to increased activity of oleate desaturase enzyme (Anderson et al., 2002). High temperature $\left(30-33^{\circ} \mathrm{C}\right)$ during pod filling to harvesting stage reduces the linoleic acid content in peanut oil (Dwivedi et al., 1996, Golombek et al., 1995). Molecular markers play important role in screening of groundnut germplasms for high oleic acid contents due to their polymorphic nature, reproducibility of results and time saving nature (Janilla et al., 2016, Pandey et al., 2014, Pramanik et al., 2019). The linked allele-specific (Chen et al., 2010) and cleaved amplified polymorphic sequences (CAPS) (Chu et al.,2009) markers for both the ahFAD2 genes (ahFAD2A and ahFAD2B) are available for use in molecular breeding. Fatty acid composition of groundnut oil is an important trait from human nutrition point of view as well as oil stability during the storage.

Consuming oils with high levels of oleic acid is preferred because oleic acid may be beneficial to human health by reducing lowdensity lipoproteins (LDL), maintaining highdensity lipoproteins (HDL), slowing down atherosclerosis, and reversing the inhibitory effect of insulin production (Vassiliou et al., 2009). Demand of peanut with High Oleicis increasing day by day both in domestic and international markets, so the present study was undertaken with the objectives: Screening of groundnut advance breeding lines and germplasms for yield and its attributes along with leaf area index, marker assisted selection for high oleic acid content.

\section{Materials and Methods}

Plant material consisted 48 genotypes were received from Directorate of Groundnut Research, Junagadh, Gujrat. Material consisted7 check groundnut varieties i.e., TG 26, GPBD4, KDG128, ICGS44, Sunoleic95 R, JGN3 and Gangapuri;20 uncharacterized germplasm lines i.e. ICGV 8113, ICGV 13248, ICGV 7996, ICGV 9268, ICGV 9525, ICGV 13231, ICGV 9112, ICGV 13228, ICGV 5647, ICGV 13270, ICGV 13533, ICGV 6673, ICGV 1441, ICGV 13520, ICGV 8059, ICGV 9935, ICGV 13245, ICGV 13552, ICGV 10447, ICGV 9081 and 21 advance breeding lines obtained from the cross ICGV $98432 \mathrm{X}$ ICG 7166 at DGR, Junagadh. 


\section{Morpho-physiological Characterization}

The field experiment was conducted at research farm of Department of Genetics and Plant Breeding, College of Agriculture, Gwalior during kharif season 2018-19.The sowing was done in Randomized Block Design with two replications. Each entry was grown in two rows having $30 \mathrm{~cm}$ row to row and $10 \mathrm{~cm}$ plant to plant distance. The yield and its attributing characters via; days to $50 \%$ flowering, days to maturity, number of primary branches, number of secondary branches, number of mature pods per plant, pod yield per plant, kernel yield per plant, hundred pod weight, hundred kernel weight, shelling percentage sound mature kernel percent and leaf area were recorded time to time.

\section{Statistical analysis}

The analysis of variance (ANOVA) of morphological traits for standard error (S.E.), and coefficient of variation (CV) was performed along with the coefficient of correlation among all the morphological traits using SPSS ver.19 software. The similarity matrices was used to construct a dendrogram for all the genotypes using NTSYS-pc based on UPGMA.

\section{Molecular characterization}

\section{PCR amplification and agarose gel electrophoresis}

Genomic DNA was extracted from young leaf tissue of groundnut by modified CTAB (Cetyl Trimethyl Ammonium Bromide) method (Murray and Thompson 1980; Tiwari et al., 2017). Allele specific primers were used for screening of groundnut germplasm for high oleic acid contents (Chu et al., 2009, Chen et al., 2010) (Table 1). Polymerase Chain Reaction for each allele-specific primer was performed in iCycler TM system (BIO-RAD, USA). PCR master mix was prepared using genomic DNA of groundnut genotypes (20 ng), $0.5 \mu \mathrm{M}$ forward primer, $0.05 \mu \mathrm{M}$ control reverse primer, $0.45 \mu \mathrm{M}$ allele-specific reverse primer (depending on the target amplicon) and $5 \mu \mathrm{l}$ polymerase master mix. PCR programming were performed at $94^{\circ} \mathrm{C}$ for 4 min denaturing temperature, followed by 35 cycles of $94^{\circ} \mathrm{C}$ for $1 \mathrm{~min}, 63^{\circ} \mathrm{C}$ to $66^{\circ} \mathrm{C}$ (depending on the target primer) for $1 \mathrm{~min}$, and $72^{\circ} \mathrm{C}$ for $1 \mathrm{~min}$, and then extension at $72^{\circ} \mathrm{C}$ for $10 \mathrm{~min}$ and finally storing at $4^{\circ} \mathrm{C}$. For the wild-type fragment F435WT-R (193 bp) was amplified at $63^{\circ} \mathrm{C}$ annealing temperature. For the fragment $(203 \mathrm{bp})$ containing substitution F435 SUB-R amplification annealing temperature was $64^{\circ} \mathrm{C}$ while for the fragment (195 bp) containing insertion F435 INS-R the annealing temperature was $66^{\circ} \mathrm{C} . \mathrm{PCR}$ products were resolved on a $2.5 \%$ agarose gel stained with ethidium bromide by electrophoresis at $110 \mathrm{~V}$ for $2 \mathrm{~h}$. The separated fragment was observed under UV trans-illuminator gel documentation system (UVP Chemidoc). The gel scoring of groundnut genotypes was done on the basis of difference in allele size of amplified bands. The major allele frequency, number of alleles per locus, polymorphism information content (PIC) and gene diversity was analyzed using Power Marker v3.25 software (Liu and Muse, 2005). The dendrogram based on unweighted pair group method for arithmetic average (UPGMA) and bootstrap value of 1000 permutations was constructed using MEGA 6.0 software (Tamura, Dudley, Nei, and Kumar, 2007).

\section{Estimation of nutritional quality}

Selected 20 groundnut advance breeding lines and genotypes having higher yield were considered for taking observations on various qualitative traits. Protein, fatty acid and oil concentration were measured with 
near- infrared reflectance spectroscopy (NIRS) (NIR Systems model XDS monochromator, FOSS Analytical AB, Sweden, Denmark) at ICRISAT, Hyderabad. About 100-150 seeds of each groundnut genotype were scanned twice using NIRS. Calibration equations were developed in the laboratory and validated for estimation of oil, protein and fatty acid concentration in groundnut seeds (Unpublished data).

\section{Results and Discussion}

\section{Morphological characterization}

Range value for days to $50 \%$ flowering was between 24 to 35, days to maturity between 97 to 110 days, number of primary branches was between 4 to 7 , number of secondary branches 4 to 8 , sound mature karnel 61 to 89 , hundred karnel weight 34 to 56 , hundred pod weight 78 to 102 and karnel yield per plant was 62 to 72 gm. The coefficient of correlation among different traits was analyzed using SPSS ver. 19 software at $1 \%$ and 5\%, significant level respectively (Table 3). Significant and positive correlation was found between days to $50 \%$ flower and days to maturity ( $\mathrm{r}=0.353)$, and grain yield $(\mathrm{r}=0.369)$ at $5 \%$ significance level (Table 2). Highly significant and positive correlation was found between number of pods per plant $(\mathrm{r}=0.399)$, number of seeds per plant $(\mathrm{r}=0.575)$ and harvest index $(\mathrm{r}=0.400)$ at $1 \%$ significance level. The number of branches per plant was highly significant with number of pods per plant $(\mathrm{r}=0.635)$ and number of seed per plant $(\mathrm{r}=0.556)$ at $1 \%$ significance level.

Mean value of all the observed morphological traits was considered for phylogenetic analysis using NTSYS ver.2.0 software. All the genotypes are grouped into two major clusters EI and EII containing 42 and 6 genotypes, respectively. The clusters are further subclustered showing similar characters. The six germplasm ICGV 7996, ICGV 13533, ICGV 13520, ICGV 6673, ICGV 9525 and ICGV 5647 show distinct characteristics and not having any of the check varieties (Fig. 1). The 2D plot formed between kernel yield per plant and 100 pod weight (Fig. 2) as these two traits are major yield contributing characters. The 2D plot formed 4 clusters and SUNOLEIC 95R grouped in cluster II. Check varieties TG 26, KDG128and Sunoleic 95R are forming same group with high oleic acid advance lines (AOL) and 3 germplasm ICGV 13248, ICGV 8003 and ICGV 9268 showing similar morphological characters.

\section{Marker assisted selection for high oleic acid content in groundnut}

A set of 6 primers specific for oleic acid contents were selected for validation of groundnut germplasms. Out of them 4 markers i.e., F435-SUB F435-INS, FAD2B-F + FAD2$\mathrm{R}$, FAD2B-F + FAD2B-A + FAD2-R generated polymorphic bands. These validated markers were selected for the further studies and screening of grounndut genotypes for high oleic acid contents.

The gene diversity and Polymorphic Information Contents (PIC) value ranges between $0.49-0.65$ and $0.37-0.58$ respectively (Table 4). A total of 13 alleles were osberved and number of alleles per locus was 2 to 4 . The CAPS marker FAD2B-F + FAD2-R shows higher genetic diversity (0.4167) and PIC value (0.5817), where as the SSR primer F435-INS reveals lowest gene diversity (0.5417) and PIC value (0.3733). The major allele frequency for FAD2B-F + FAD2-R was observed 0.4167 which is lowest; while primer F435-SUB evident highest major gene frequency (0.6042) (Table 4). The 15 unknown germplasm and one high oleic acid line shows amplification with F435-F, F435IC-R, and F435WT-R at 193 bp was amplified. out of 48 taregeted genotypes 21 
shows band pairing with F435-F, F435IC-R, and F435-SUB primer at $203 \mathrm{bp}$ amplification. The primer combination F435-F, F435IC-R, and F435-INS amplified in JGN-3 cultivar, 6 high oleic acid lines and 13 unknown germplasm; giving product size $195 \mathrm{bp}$.The CAPS markers combination FAD2B-F + FAD2-R and FAD2B-F + FAD2B-A + FAD2$\mathrm{R}$ amplifies the $\mathrm{B}$-genome.

The genetic relationships among groundnut advance breeding lines and germplasms are presented based on Unweighted Neighbor Joining (UNJ) dendrogram (Fig. 3). All the genotypes were grouped into five major clusters. The advance breeding line AOL 9 was distinct and not grouped with any of the clusters. Cluster I contain 4 germplasms, while 3 germplasm and one advance breeding line were grouped in cluster II including JGN 3, one of the major variety of Madhya Pradesh state. Cluster III was having 4 germplasms and 2 AOL, while cluster IV grouped with 3 germplams, 4 AOL and 3 check varieties including TG 26, GPBD 4 and Gangapuri. Cluster $\mathrm{V}$ formed group with sunoleic $95 \mathrm{R}$, KDG 128, 10 AOLs and one germplasm ICGV 9081 while cluster VI grouped with 3 AOLs and 4 groundnut germplasms.

\section{Nutritional Quality Traits Analysis}

Oil, fatty acid profiles and proteinpercentage was analysed in selected high yielding genotypes of groundnut. Highest oil i.e., 57\% was found for AOL 6 and lowest for JGN 3 (46\%). Oleic acid was ranged between 62 to $29.7 \%$ for sunoleic $95 \mathrm{R}$ and GPBD 4 respectively, linolic acid between 22 to $49 \%$ for GBPD4 and Sunoleic 95 R respectively.

Palmitic acid was ranging between 10.22 (sunoleic $95 \mathrm{R}$ ) to $14.07 \%$ (Gangapuri), stearic acid 1.05 (AOL3) to 3.27 (Gangapuri) (Fig. 4, Table 4). Groundnut varieties with high oleic/linoleic acid ratios (O/L) have become preferred by the peanut industry due to their increased shelf life and improved health benefits. O/L ratio was ranged from 2.78 to 0.59. Sunoleic $95 \mathrm{R}$ variety was represented highest $\mathrm{O} / \mathrm{L}$ ratio (Fig. 5). Cluster analysis based on diversity was performed using the UPGMA (Fig. 6). The mean value of fatty acids for groundnut variety falling in each cluster was presented in the generated dendrogram for distinguished into two clusters (I, and II). Cluster I consisted two varieties viz.

Sunoleic $95 \mathrm{R}$ and AOL-3. Sunoleic $95 \mathrm{R}$ exhibited highest oleic content while AOL-3 lowest stearic acid content. Cluster II further divided into two sub cluster and consited 18 variety of ground nut. Principal component analysis (PCA) was done by considering four variables viz. Linoleic acid, oleic acid, palmitic acid and Stearic acid simultaneously. The pattern of variations illustrated by the PCA described by correlation coefficients determined for pair-wise association of the traits (Fig. 7). The PCA correlation depicted that which variety possessed higher and lower fatty acid content occupying unique position towards the graph. The variety Sunoleic $95 \mathrm{R}$ came as out group showing the maximum diversity. Total protein was ranging between $18.5 \%$ to $31.68 \%$ for ICGV 7996 to AOL 18 respectively. Moisture level was between 2.9 to 11.4 for AOL 3 and ICGV 8059 respectively (Table 4).

Peanut with high oleic acid is preferred over normal peanut due to its multiple health benefits, extended shelf life and for industrial purposes. Therefore, screening of groundnut germplasm for high oleic acid contents and its utilization for improvement of peanut for higher oxidative stability and better dietary properties is one of the important breeding objectives worldwide. 
Table.1 Detail of gene specific primers for high oleic acid content of groundnut

\begin{tabular}{|c|c|c|c|c|}
\hline $\begin{array}{l}\text { Markers } \\
\text { Name/Type }\end{array}$ & $\begin{array}{l}\text { Annealing } \\
\text { Temp }\end{array}$ & Sequence (5' -> 3') & $\begin{array}{l}\text { Allele } \\
\text { Size } \\
\text { (bp) }\end{array}$ & References \\
\hline $\begin{array}{c}\text { FAD2A } \\
\text { (SENSE)/CAPS }\end{array}$ & 48.5 & $\begin{array}{l}\text { GATTACTGATTATTTGA } \\
\text { CTT }\end{array}$ & 598 & Chu et al.,2009 \\
\hline $\begin{array}{c}\text { FAD2A } \\
\text { (ANTISENS) / } \\
\text { CAPS }\end{array}$ & 48.5 & $\begin{array}{l}\text { CCAACCCAAACCTTTCA } \\
\text { GAG }\end{array}$ & 228 & Chu et al.2009 \\
\hline F435-F/AS-PCR & $\begin{array}{c}\text { As per } \mathrm{R} \\
\text { primer mixed }\end{array}$ & $\begin{array}{c}\text { ATCCAAGGCTGCATTCT } \\
\text { CAC }\end{array}$ & & Chen et al., 2010 \\
\hline $\begin{array}{l}\text { F435IC-R/ AS- } \\
\text { PCR (CONTROL) }\end{array}$ & $\begin{array}{c}\text { As per } \mathrm{R} \\
\text { primer mixed }\end{array}$ & $\begin{array}{c}\text { CTCCCTGGTGGATTGTT } \\
\text { CATG T }\end{array}$ & 250 & Chen et al.,2010 \\
\hline $\begin{array}{l}\text { F435WT-R/ AS- } \\
\text { PCR }\end{array}$ & 63 & ACTTCGTCGCGGTCG & 193 & Chen et al.,2010 \\
\hline $\begin{array}{c}\text { F435SUB-R / AS- } \\
\text { PCR }\end{array}$ & 64 & $\begin{array}{c}\text { TGGGACAAACACTTCG } \\
\text { TT }\end{array}$ & 203 & Chen et al.,2010 \\
\hline $\begin{array}{l}\text { F435INS-R / AS- } \\
\text { PCR }\end{array}$ & 66 & $\begin{array}{c}\text { AACACTTCGTCGCGGTC } \\
\mathrm{T}\end{array}$ & 195 & Chen et al.,2010 \\
\hline FAD2B-F / CAPS & $\begin{array}{c}\text { As per } \mathrm{R} \\
\text { primer mixed }\end{array}$ & $\begin{array}{c}\text { CAGAACCATTAGCTTTG } \\
\text { TAGTA GTG }\end{array}$ & 736 & Chu et al.,2009 \\
\hline FAD2B-A / CAPS & 53 & AACATTCGTCGCGGTTT & 263 & Chu et al.,2009 \\
\hline FAD2-R / CAPS & 51 & $\begin{array}{c}\text { CTCTGACTATGCATCAG } \\
\text { AACTT GT }\end{array}$ & 171 & Chu et al., 2009 \\
\hline
\end{tabular}

(NOTE: F: Forward, R: Reverse)

Table.2 Analysis of correlation coefficient of mean value of yield attributing morphological traits in mustard germplasm using SPSS V19 software

\begin{tabular}{|c|c|c|c|c|c|c|c|c|c|c|}
\hline \multicolumn{11}{|c|}{ Correlations } \\
\hline & $\mathrm{DF}$ & KYD & NPB & NSB & SMK & HKW & NPP & HPW & DM & KWP \\
\hline DF & 1 & & & & & & & & & \\
\hline KYD & -.148 & 1 & & & & & & & & \\
\hline NPB & .144 & .263 & 1 & & & & & & & \\
\hline NSB & .040 & $.309^{\circ}$ & $.736^{\prime \prime}$ & 1 & & & & & & \\
\hline SMK & -.040 & -.137 & -.327 & -.182 & 1 & & & & & \\
\hline HKW & -.075 & -.015 & -.171 & -.098 & .190 & 1 & & & & \\
\hline NPP & $-300^{\circ}$ & $.762^{* *}$ & .200 & .136 & -.109 & .110 & 1 & & & \\
\hline HPW & -.097 & .243 & .216 & .232 & -.095 & .210 & .154 & 1 & & \\
\hline DM & -.141 & -.230 & -.053 & .026 & .135 & .063 & -.204 & -.183 & 1 & \\
\hline KWP & -.209 & -.054 & -.059 & -.025 & -.050 & $.371^{*}$ & -.121 & -.054 & .218 & 1 \\
\hline
\end{tabular}

*. Correlation is significant at the 0.05 level (2-tailed).

**. Correlation is sianificant at the 0.01 level (2-tailed). 
Table.3 Major allele frequency, Allele No., Gene Diversity and PIC Values of molecular markers in groundnut germplasms

\begin{tabular}{|c|c|c|c|c|c|}
\hline Marker & $\begin{array}{c}\text { Major } \\
\text { Allele } \\
\text { Frequency }\end{array}$ & Allele No & $\begin{array}{c}\text { Gene } \\
\text { Diversity }\end{array}$ & Heterozygosity & PIC \\
\hline F435-SUB & 0.6042 & 4.0000 & 0.5267 & 0.5208 & 0.4468 \\
\hline F435-INS & 0.5417 & 2.0000 & 0.4965 & 0.2917 & 0.3733 \\
\hline FAD2B-F + FAD2-R & 0.4167 & 3.0000 & 0.6554 & 0.0000 & 0.5817 \\
\hline FAD2B-F + FAD2B-A + & 0.5000 & 2.0000 & 0.5000 & 0.0000 & 0.3750 \\
\hline FAD2-R & 0.5156 & 2.7500 & 0.5447 & 0.2031 & 0.4442 \\
\hline Mean & & & & & \\
\hline
\end{tabular}

Table.4 Nutritional traits values of groundnut germplasm

\begin{tabular}{|c|c|c|c|c|c|c|c|c|}
\hline $\begin{array}{c}\text { Varieties, } \\
\text { cultivar and } \\
\text { germplasm }\end{array}$ & OIL & $\begin{array}{c}\text { Linoleic } \\
\text { acid } \\
\text { PUFA }\end{array}$ & $\begin{array}{c}\text { Oleic } \\
\text { acid } \\
\text { MUFA }\end{array}$ & $\begin{array}{c}\text { Palmitic } \\
\text { acid } \\
\text { SFA }\end{array}$ & $\begin{array}{c}\text { Stearic } \\
\text { acid } \\
\text { SFA }\end{array}$ & O/L & PROTEIN & MOISTURE \\
\hline JGN-3 & 46.22 & 43.72 & 32.33 & 12.38 & 3.21 & 0.73 & 25.91 & 6.76 \\
\hline AOL 21 & 48.35 & 40.87 & 36.42 & 12.51 & 2.17 & 0.89 & 25.21 & 5.76 \\
\hline AOL 19 & 48.73 & 39.52 & 37.87 & 12.57 & 1.91 & 0.95 & 23.71 & 7.85 \\
\hline AOL 16 & 49.32 & 43.11 & 33.72 & 12.62 & 3.13 & 0.78 & 26.73 & 5.61 \\
\hline AOL3 & 49.65 & 30.72 & 48.79 & 13.57 & 1.05 & 1.58 & 24.74 & 2.95 \\
\hline AOL 18 & 49.84 & 35.59 & 42.27 & 11.26 & 3.12 & 1.18 & 31.68 & 6.91 \\
\hline ICGV 13533 & 50.17 & 46.24 & 31.48 & 12.47 & 2.33 & 0.68 & 26.33 & 6.92 \\
\hline AOL 17 & 51.30 & 40.34 & 37.25 & 12.72 & 2.27 & 0.92 & 21.58 & 6.76 \\
\hline ICGV 8059 & 51.33 & 34.90 & 39.83 & 13.54 & 2.44 & 1.14 & 21.62 & 11.42 \\
\hline ICGV 13520 & 51.51 & 42.84 & 33.06 & 13.76 & 2.54 & 0.77 & 20.33 & 6.26 \\
\hline AOL 5 & 51.58 & 38.69 & 39.29 & 11.77 & 2.89 & 1.01 & 27.13 & 6.83 \\
\hline KDG - 128 & 51.70 & 43.15 & 33.74 & 13.17 & 2.18 & 0.78 & 21.43 & 6.46 \\
\hline ICGV 7996 & 51.90 & 37.64 & 41.62 & 12.12 & 2.10 & 1.10 & 18.50 & 7.90 \\
\hline SUNOLEIC - & 53.32 & 22.26 & 61.99 & 10.22 & 2.68 & 2.78 & 21.48 & 6.17 \\
\hline 95 R & & & & & & & & 6.32 \\
\hline AOL 20 & 53.53 & 35.34 & 42.81 & 12.00 & 1.97 & 1.21 & 21.67 & 6.37 \\
\hline ICGV 1441 & 54.42 & 41.24 & 35.81 & 12.38 & 2.70 & 0.86 & 24.53 & 5.97 \\
\hline AOL 4 & 54.48 & 46.12 & 31.36 & 13.91 & 2.20 & 0.67 & 20.31 & 6.95 \\
\hline GANGAPURI & 55.92 & 46.11 & 28.26 & 14.07 & 3.27 & 0.61 & 24.16 & 7.71 \\
\hline GPBD - 4 & 56.13 & 49.67 & 29.73 & 13.87 & 1.96 & 0.59 & 21.46 & 5.17 \\
\hline AOL 6 & 57.34 & 39.64 & 41.15 & 11.32 & 3.18 & 1.06 & 22.37 & 4.91 \\
\hline
\end{tabular}


Fig.1 3D clustering of groundnut germplasms for morphological characters



Fig.2 2D Plot between kernel yield and 100 pod weight of groundnut germplasms

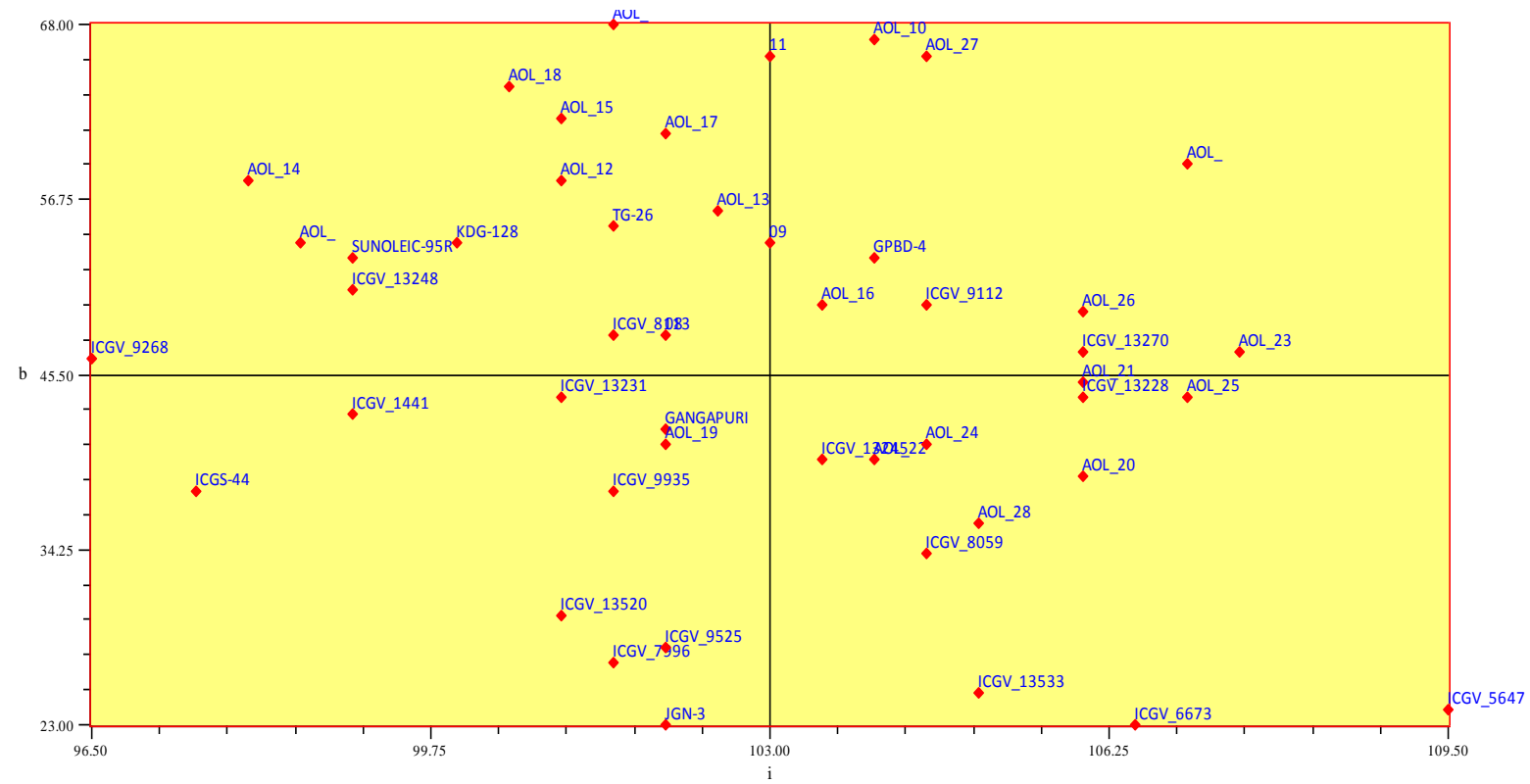


Fig.3 Dendrogram of groundnut germplasm based on allele specific markers for high oleic acid contents

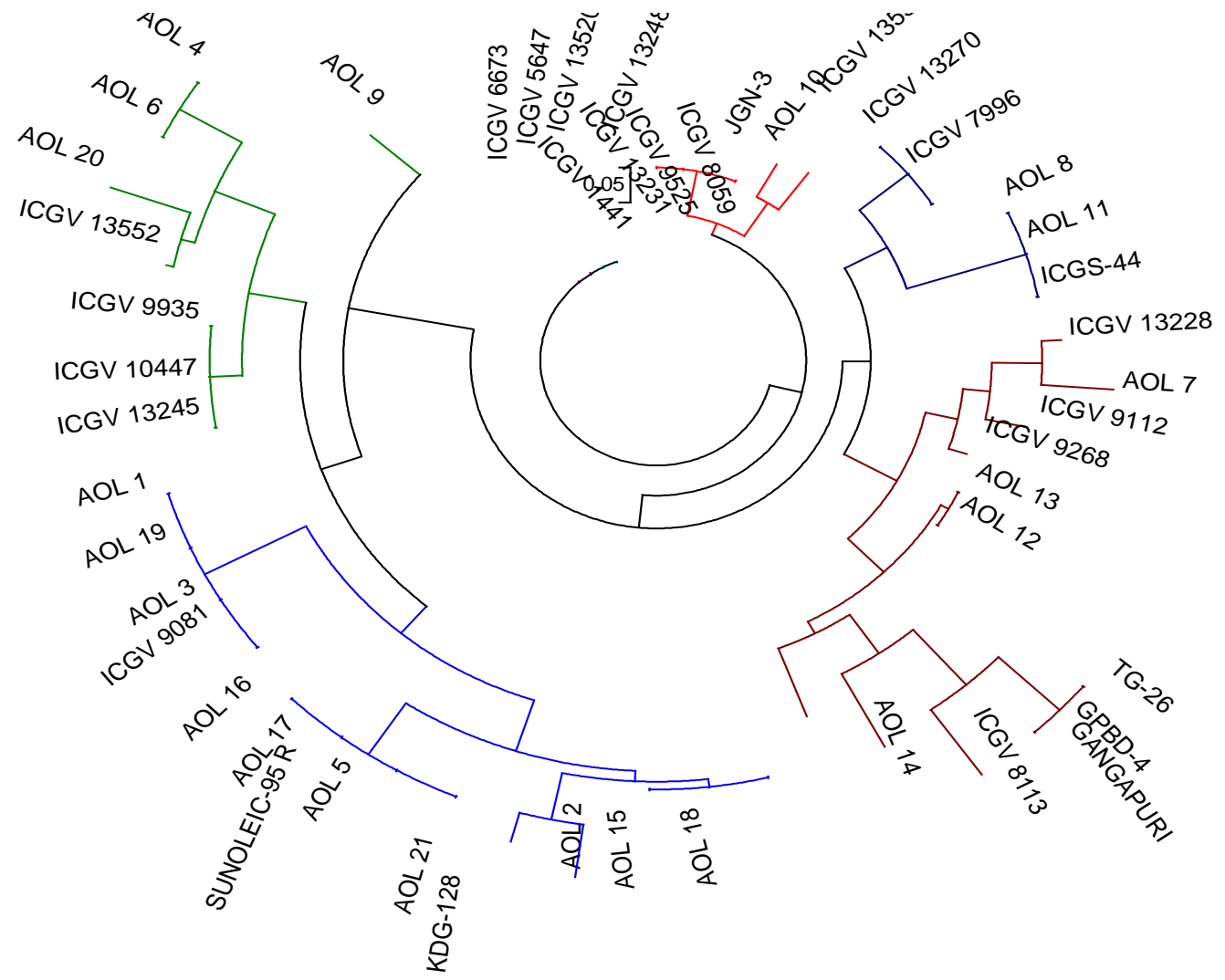

Fig.4 Comparative profiling of nutritional traits including oil, fatty acid profiling and protein content of groundnut germplasm lines

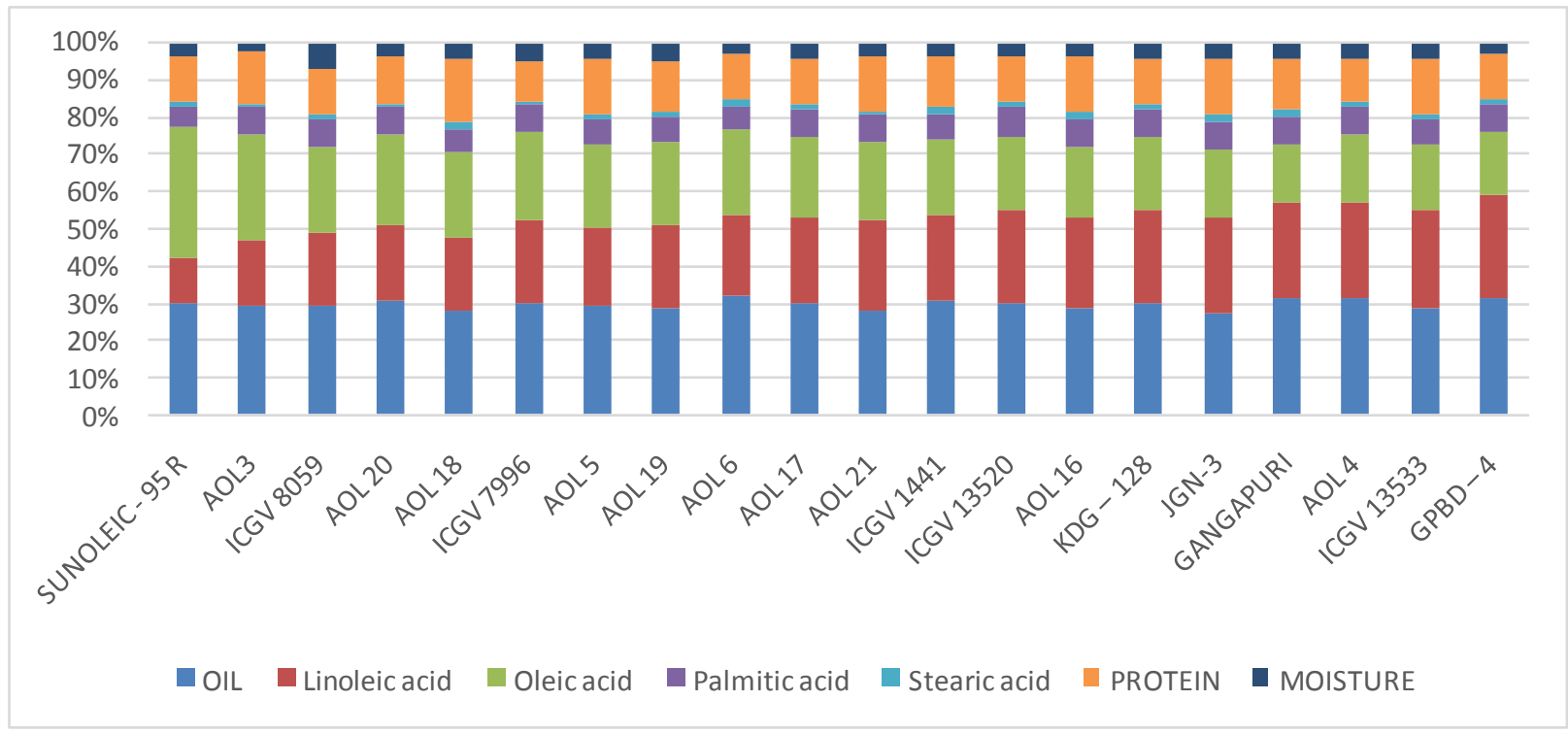


Fig.5 Graphical representation fatty acid profile of groundnut variety



Fig.6 Cluster analysis of groundnut varieties for fatty acid profiling

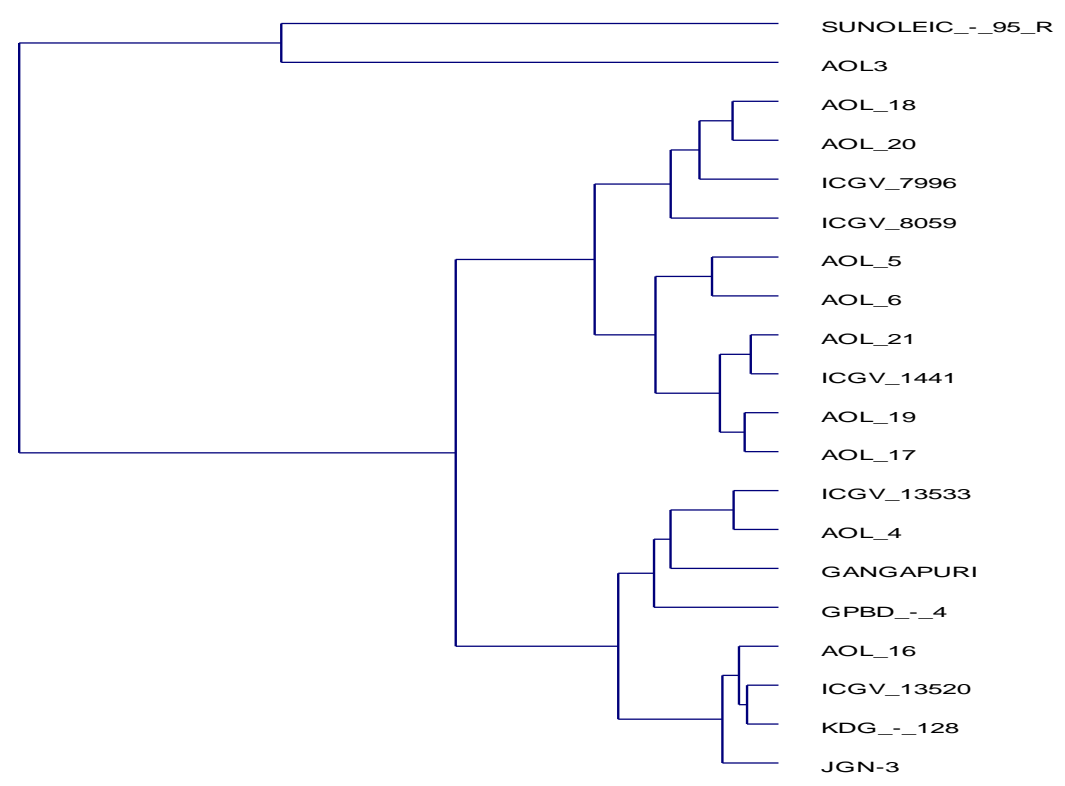


Fig.7 Principal components analysis of groundnut genotypes based on fatty acid profiling

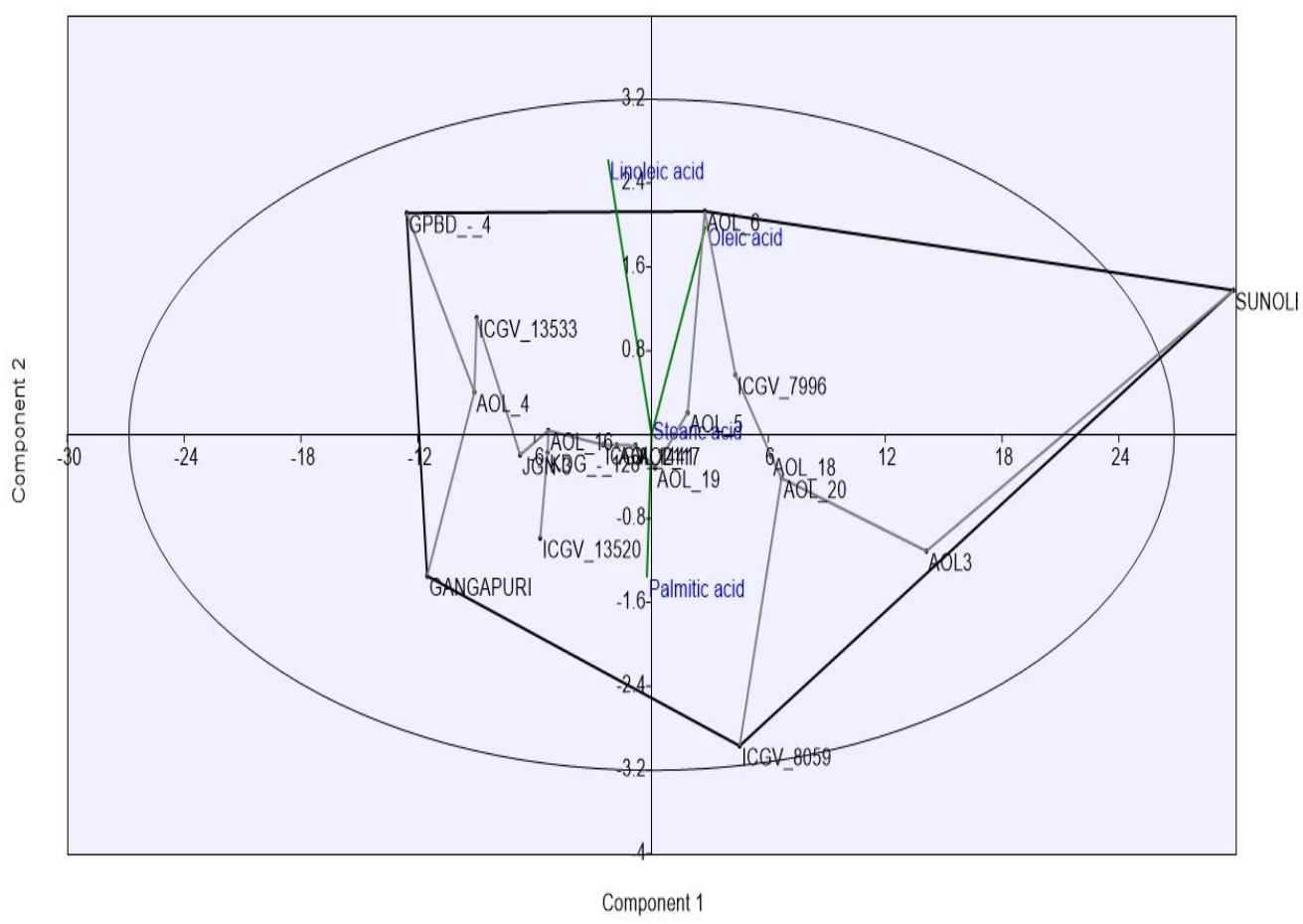

The flavour, stability, shelf life, and nutritional quality of peanut and peanut products are dependent on the fatty acid composition (ratio of saturated, monounsaturated, and polyunsaturated lipids) of the extracted oil (Arya et al., 2016). Molecular markers are one of the most important tools being used widely for legume crop improvement including groundnut (Pramanik et al., 2019, Sahu et al., 2020; Mishra et al., 2020; Bhawar et al., 2020). Availability of molecular markers linked to the $a h F A D 2$ gene has facilitated markerassisted breeding for desirable fatty acid (Bera et al., 2019). Chen et al., (2010) designed F345-type mutate primer having different annealing temperature. In our study four markers i.e., F435-SUB, F435-INS, FAD2B-F + FAD2-R and FAD2B-F + FAD2B-A + FAD2-R found suitable for screening of oleic acid contents in groundnut. Barkley et al., (2011) reported real time PCR for identification of genotypes associated with oleic acid for improving the breeding efficiency of the traits. Although up to 12 fatty acids have been reported in groundnut, generally palmitic acid (16:0) constitutes nearly $10 \%$ and the oleic (18:1) and linoleic acid (18:2) proportions together make up $80 \%$ of the fatty acid composition in groundnut. Several marketable benefits of oleic acid drive the breeding effort toward producing high oleic peanuts. First, oleic acid, a monounsaturated fatty acid, has 10-fold higher autoxidative stability than linoleic acid (Chen et al., 2010), therefore, high oleic/linoleic $(\mathrm{O} / \mathrm{L})$ peanut has a longer shelf life than normal $\mathrm{O} / \mathrm{L}$ peanut. The correlation study showed strong negative correlation between oleic and linoleic acid. In present study oleic acid was highest for sunoleic $95 \mathrm{R}(62 \%)$ and lowest for GPBD4 (29.7 \%) while leinolic acid was lowest for Sunoleic $95 \mathrm{R}(22 \%)$ and highest for GBPD 4 (49 \%). The result was further confirmed with the genotyping for the $a h F A D$ mutants in the population and their 
respective phenotyping effect for different fatty acids. Present study AOL 6 is most superior advance breeding line among the studied groundnut germplasms having oil $57.34 \%$ and oleic acid $41.15 \%$ while germplasm line ICGV 7996 is having $51.9 \%$ oil and $41.62 \%$ oleic acid. These identified lines could be used further for expression analysis to see effect of gene based marker at particular environment.

\section{Acknowledgement}

Authors are thankful to DGR, Junagadh for providing seed material of germplasm and advance breeding lines and ICRISAT, Hyderabad for doing nutritional profiling using NIRS, facility.

\section{References}

Arya SS, Salve AR, Chauhan S. Peanuts as functional food: a review. J Food Sci Technol. 2016; 53:31-41.

Barkley, A.N., Isleib, T.G., Wang, M.L., Pittman, R.N. (2013) Genotypic effect of ahFAD2 on fatty acid profiles in six segregating peanut (Arachis hypogaea L.) populations. BMC Genetics, 14: 62.

Bhawar, P. C., Tiwari, S., Tripathi, M. K., Tomar, R. S. and Sikarwar, R. S. (2020). Screening of Groundnut Germplasm for Foliar Fungal Diseases and Population Structure Analysis Using Gene Based SSR Markers. Current Journal of Applied Science and Technology, 39(2), 75-84. https://doi.org/10.9734/cjast/2020/v39i 230500

Bera SK, Kamdar JH, Kasundra SV, Patel SV, Jasani MD, Maurya AK, et al., (2019) Steady expression of high oleic acid in peanut bred by marker-assisted backcrossing for fatty acid desaturase mutant alleles and its effect on seed germination along with other seedling traits. PLoS ONE 14(12): e0226252.

Chen, Z., Wang, M.L., Barkley, N.A., Pittman, R.N. (2010) A simple allelespecific PCR assay for detecting FAD2allelesinbothAandB genomes of the cultivated peanut for high-oleate traits election. Plant Mol. Biol. Rep. 28: 542-548.

Chu, Y., Wu, C.L., Holbrook, C.C., Tillman, B.L., Person, G., Ozias Akins, P. Marker-assisted selection to pyramid nematode resistance and the high oleic trait in peanut. Plant Genome 4: 110117 (2011).

Dwivedi SL, Nigam SN, Rao RN, Singh U, Rao KVS. (1996) Effect of drought on oil, fatty acids and protein contents of groundnut (Arachis hypogaea L.) seeds. Field crops research: 48(2-3): 125-133.

Gorbet, D.W., Knauft, D.A. (1997). Registration of 'SunOleic 95R' peanut. Crop Sci. 37: 1392

Janila, P., Pandey, M.K., Shasidhar, Y., Variath, M.T., Sriswathi, M., Khera, P., Manohar, S.S., Nagesh, P., Vishwakarma, M.K., Mishra, G.P., Radhakrishnan, T. (2016b) Molecular breeding for introgression of fatty acid desaturase mutant alleles (ahFAD2A and ahFAD2B) enhances oil quality in high and low oil containing peanut genotypes. Plant Sci. 242: 203-13.

Liu K. and Muse S. 2004. Power Marker: new genetic data analysis software, version 27.

MishraN, Tripathi M.K., Tiwari S, Tripathi N and Trivedi H.K. (2020) Morphological and Molecular Screening of Soybean Genotypes against Yellow Mosaic Virus Disease. Legume Research. doi 10.18805/LR4240

Moore, K.M., Knauft, D.A. (1989) The inheritance of high oleic acid in 
peanut. J Hered 80: 252-253.

Murray M. G. and Thompson W. F. (1980). Rapid isolation of high molecular weight plant DNA. Nucleic Acids Res., 8: 4321-4325.

Norden, A.J., Gorbet, D.W., Knauft, D.A., Young C.T. (1987) Variability in oil quality among peanut genotypes in the Florida breeding program, Peanut Sci. 147: 11

Pandey, M.K., Wang, M.L., Qiao, L., Feng, S., Khera, P., Wang, H., et al., (2014) Identification of QTLs associated with oil content and mapping FAD2 genes and their relative contribution to oil quality in peanut (Arachis hypogaea L.). BMC Genet 15: 133.

Pramanik A, Sushma Tiwari, M.K. Tripathi, R.S. Tomar and A. K. Singh. (2019) Molecular characterization of groundnut (Arachis hypogaea L.) germplasm lines for yield attributed traits. Indian J. Genet., 79(1): 56-65
Sahu V K, Tiwari S, Tripathi M K, Gupta N, Tomar R S. and Yasin M (2020) Morpho-physiological and biochemical traits analysis for Fusarium wilt disease using gene-based markers in desi and Kabuli genotypes of chickpea (Cicer arietinum L.)" Indian J. Genet., 80(2) 163-172

Töpfer, R., Martini, N. and Schell J. (1995). Modification of plant lipid synthesis. Science 268: 681-686.

Tiwari S, Tripathi M K, Kumar N, Tomar R S, Joshi E, Tiwari R, Gupta R and Singh A $\mathrm{K}$ (2017) Improvement of Groundnut for Fatty Acids using Marker Assisted Breeding Approaches. Int. J. Pure App. Biosci. 5 (6): 59-63

Tiwari Sushma, Tomar R. S., Tripathi M. K. and AhujaAshok (2017) Modified Protocol for Plant Genomic DNA Isolation. Indian Res. J. Genet. \& Biotech. 9(4) $478-485$

\section{How to cite this article:}

Tinee Adlak, Sushma Tiwari, Neha Gupta, M. K. Tripathi, R. S. Sikarwar, Ritu Sastya and Versha Gupta. 2021. Assessment for Yield and Nutritional Profiling of Groundnut with the Help of Allele Specific Markers for Desirable Fatty Acids. Int.J.Curr.Microbiol.App.Sci. 10(02): 1625-1637. doi: https://doi.org/10.20546/ijcmas.2021.1002.193 